\title{
Representation of Elite Values of the Modern Society in Minimalist Living Architectural Space
}

\author{
Tatyana Valentinovna Gudkova ${ }^{1 *}$ and Alexei Alexeyevich Gudkov² \\ 'Novosibirsk State Academy of Architecture and Arts, Novosibirsk, Russia; \\ t.v.gudkova@gmail.com \\ ${ }^{2}$ Novosibirsk State University of Architecture and Civil Engineering, Novosibirsk, Russia
}

\begin{abstract}
Consumerism prepared consciousness of people for perception of goods through signs. Architecture acting as a commodity is also a carrier of signs that allow not only being sold, but also the creation of belonging to a certain stratum or a social group in the consumer's mind. An opposite tendency (anti-consumerism) made the consumer society refashion itself so as not to lose the buyer who consciously began to refuse to buy goods. The minimalist movement that has emerged in the society, which is based on a minimalist lifestyle where a person stops paying attention to things, sets the person's focus on the main social benefits that are not affordable for the majority (for example freedom, time, nature, peace, space). This creates a social-consumerist precedent when minimalism as a lifestyle allows retaining the individual as a buyer. The main goal of this article is to look into representations of such benefits of the modern consumer society as the value of freedom, the value of time, the value of nature, the value of peace in the minimal architectural living space, which shape the overall value - the value of physical space. Architectural living space, acting both as a physical and social category, reflects the style and the way of living of its owner. The genetic connection with the architecture of modernism allowed interpolation between the modernism ideas, elite social benefits and their representation in the architectural minimalist living space: between the "free plan" of Le Corbusier and the "value of freedom";"organic architecture" of F.L.Wright and the "value of nature"; "Less is more" of Mies van "der Rohe and the "value of time"; between the "organic architecture" of F.L. Wright and "Less is more" of Mies van der Rohe and the "value of peace".
\end{abstract}

Keywords: Anthropology and Sociology of Architecture, Architectural Space, Consumerism Existence of Man in an Artificial Environment, Social Space, Sociology of Architectural Space

\section{Introduction}

Nothing has changed since Sidney J. Levy ${ }^{1}$ back in the middle of the $20^{\text {th }}$ century said that people buy things not only for what they can do but also for what they mean. But at the current stage of the consumer society development, on the one hand, thoughts of inevitable coming of abundance and immorality of wastefulness are instilled in the mind of a consumer. This tendency displays itself as anti-consumerism, which is based on custodian consumption, voluntary simplicity lifestyle up to the personal refusal of material values (asceticism) ${ }^{2}$. In response to this, the consumerism society, not to lose the consumer, formed a new group of taste preferences of an individual within the framework of eco-esthetics. On the other hand, the reign of supernational consumerism and equalization in consumption between social strata resulted in formation of a new group of valuesbenefits embodying conditions and quality of existence in the modern world. In this case, everybody wants to consume not any benefits, but those that have high importance in the existing system of values presented by the consumption culture and society. It is this form of consumption that gives a person maximal pleasure in the world of consumerism and shapes a mindset for hedonistic consumption because the needs of a person in

\footnotetext{
${ }^{*}$ Author for correspondence
} 
such a world are oriented not so much to goods, as much as what their embodiment is ${ }^{3}$. Things can be bought for money, but time, peace, freedom are not bought directly. These social values are elevated to the luxury level because not everyone can have them in the urbanized bourgeois world. Industrial goods and services are offered in all the diversity, and new elite values retain the differentiation that is indispensable in the class society. Possessing such benefits and their demonstration through stratification signs is a social manifestation, consumer's claim of belonging to the financial elite of the society.

At the present time, the customer's mind, with the assistance of advertisement and mass media, is prepared for perception of stratification signs and social benefits designated by them, which at the same time are "social shortages" sought after in the modern urbanized world (nature, peace, time and space according toBaudrillard ${ }^{4}$ ). They, along with goods and services, arouse the desire to have them in the individual's mind because they reflect dreams of freedom and independence on the society, idea of successfulness, social recognition and increased, elite comfort associated with them. Symbolic possession of time, peace, nature through stratification signs and their material embodiment in personal living space show the society the high social and material status of their owner.

The right to space is exercised via the social right to ownership and is a sign of distinction-class privilege, so space and its social marking have become of value in the consumer society. Modern architectural space, being a commodity, is oriented to consumer who has an endless desire to feel pleasure and unlimited need in material success. Through the spatial social value-related ideas about benefits being the luxuries of the modern world, and their embodiment in the architectural living space, an individual can fulfill the opportunity to assert oneself as an owner of new values - benefits and thereby fix one's high social status in the society.

In the previous article ${ }^{5}$ the minimalistic architectural space was considered with its individual features not only as a space for living, but also as a carrier of connotations that are in demand in the consumer society: open spaceas a sense association or an idea of spiritual, material, personal freedom; closed (from the outside) space - as an idea of safety, autonomy; single (interior) space with minimal zoning - as an idea of life in own rhythm; large space - as a connotation of wealth, prestige, status of its owner; empty space of interior - as a connotation of independence on artificial world (the world of things) and consumerism.
As we develop the subject of minimal architectural space connotations, let us set up a hypothesis that this presents a social phenomenon, which is a total carrier of stratification signs of elite values of the consumer societythe value of freedom, the value of comfort, the value of time, the value of peace, and the value of space. However, let us note that the value and, accordingly, the cost of a minimal living architectural space are made up of the abovementioned values.

\section{Research Methodology}

\subsection{Style and Way of Life in Minimal Living Architectural Space}

Beside the physical space perceived within limits, the essence of any architectural object reflects its social space.

There are two approaches to understanding space: 1. Physical space and social space are two different not interconnected phenomena (E. Durkheim, P. Sorokin, A. Giddens, et al.); 2. All space is social (subject of knowledge is in the man, but not in the society) (S. Simmel, E. Goffman, P. Bergerand T. Luckmann, et al.). German philosopher and sociologist G. Simmel is the originator of the space sociology. The term "social space" appears for the first time in his work "Sociology of Space"6. He considered space to be social because it was assimilated by the man who filled it with links and zones of influence, marked the limits, structured it. The second author who is important for the sociology of space is P. Bourdieu ${ }^{7}$ who combined the two approaches. According to Bourdieu, social space is a kind of a system construct consisting of "fields" (economic, political, cultural and so on). The power over them gives possession of scarce benefits, which are based on capital ${ }^{8}$.

Within the limits of this article, it is interesting to analyze works of the sociologist of modernism G. Simmel ${ }^{9}$, on which basis the characteristics of social space are distinguished: exclusiveness (uniqueness), limits (social demarcation), fixing of social forms in space (location and fixing of social interaction in space), spatial proximity and distance (remoteness or closeness of people regardless of distance), motion of space (change of location). Logically, such characteristics of social space as importance of social demarcation, fixing of social interaction, spatial proximity and distance existing in the society are also present in architectural space, which is a part of the social space. 
Just like the social space of a city organizes the life activity of an individual, the architectural living social space sets a certain style and a way of living to a person by its internal structure. According to P. Bourdieu, life style is an integral multitude of distinctive preferences. Life style can be of elite and mass nature. N. N. Melnikova ${ }^{10}$ underlines that the notion of "style" is used when talking about specific peculiarities of doing something, stable methods for solving any tasks. As applied to issues of life organization, she proposes considering life style as some integral characteristic describing a way for a person to solve basic life tasks. Melnikova specifies difference between the way of living and the life style. She understands the way of living as something that belongs to an individual and plays a certain role in the arrangement of one's own life by the person.

Life style is connected with markers of a social group and the status of its member, which form the style of behavior in society. Style of behavior of a person in a living space is set by availability of certain functional zones and links between them. A functional zone is a certain unit of living space, which is required in the functional structure of residence for life support of people who dwell in there. The links between these spatial units are not only trajectories of the person's motion set by furniture, corridors, door cases, but this is also what forms habits of living, including functional habits. These habits influence on behavioral style in general, for example, habits of moving in living space, preferences in types of domestic activity and life support. The habit of interaction with individual things and their groups surrounding a person in the living space, and interaction with the zones where these things are located (kitchen, bedroom, office, etc.) can be distinguished among them. Such space is dynamic because people act in there, i.e. social functions (sleep, waking, eating, personal hygiene, etc.), and also recurrent and single-time individual acts form a system of social acts taking place in person's dwelling, i.e. his style and way of living ${ }^{11}$.

The social individual living space shows what way of living the individual prefers - individual or joint, what social relations he is in - family or preferring solitude, what type of communication and behavior he favors while staying in this space - introvert or extravert, and what life style he chooses in this case. Living space, as the closest to the person, at the physical level should create conditions corresponding to his individual physiological and spiritual needs, which at the social level are stimulated by the consumer society by "achievement of the dream"the maximum possible stratification level and quality of life and form his style ${ }^{12}$.

In due time, A. E. Korotkovsky proposed studying architectural space (architectural form) as anthropoprojection. This idea is developed in the dissertation research by E. E. Biryukova ${ }^{13}$ where the author considers architectural space as a special method for selfobjectification by the person in the material-substantialcontinual outside world by means of anthropo-projection. The content of architectural space is a projection of the human (physical, utilitarian-household, social-cultural, spiritual) in all its aspects, and if we talk about living architecture from the social point of view, then, apart from all other things, it is a spatial anthropo-projection of individual social preferences of a person, the way of living, the life style and behavior of himself and, indirectly, social group (stratum), among which the individual reckons himself.

The anthropological approach to architecture is also considered in works by L. B. Pereverzev ${ }^{14}$, L. I. Kirsanova ${ }^{15}$, K. N. Yakunicheva ${ }^{16}$. According to the authors, a house should support the diversity of human life activity types, and for this, it is necessary to create an analogue of natural conditions for optimal existence of a person (air, light, water, heat) in the residential environment marked as the standards of comfort appropriate for a modern dwelling.

In the implemented design doctrine of "house-cars for living "the ideal house was seen without the traditional functions, which were moved outside its boundaries due to the developed infrastructure. Therefore, it was freed from furniture, things and premises, which were deemed as anachronism. Developing the idea of modernism of the "house-cars for living", minimal living space does not contain anything unnecessary, the functions are reduced to the optimal minimum a person needs in the modes: rest, sleep, waking ${ }^{14}$. Minimalism as a style expressed by architectural needs is tied in consumer's mind with simplicity and laconism, which are the main creative tools of such architecture ${ }^{17}$, but also with the notion of "modern urban way of living, which is based on an aim at success in life. It corresponds to: social activity and agility of person, his mobility; initiative and inclination to change of social status; concentration of activity and time planning; selectivity (professional skillfulness, technology-friendliness); love of freedom (right to property, right to shelter, right to privacy) and metasetting of "freedom of choice". 
If we consider the minimal living architecture from this standpoint, then the way of living it renders can be characterized as rationalistic, urbanistic via the maximally expressed functionality of life activity processes, while the outward appearance of the space follows the functionality of the processes that take place inside. Functionality of the processes going on in such a space is expressed in forms, surfaces and its elements.

Authentic features of the minimalistic architecture we have discovered earlier are also presentin living architecture of minimalism (single form of building and indivisibility of the space; importance of color and monochromatic color; emptiness, strictness, simplicity; homogeneity of surfaces and absence of parts; innovativeness in construction, in materials used and in technical equipment of building ${ }^{5}$ ). Such residential architecture and its interior solution reflect the rational way of thinking, freedom from society, things, more free time -free planning and emphasis on empty space, nothing unnecessary, refusal from buying things or minimizing it; inventory and systemizing -one thing comes, another goes, all things are in closed storage systems; self-organization of the owner -sterile order in the living space. Liberation from things allows their owner to focus on one's own life, and also to get away from the information noise. The pronounced functionality of such space is the consumer's materialized idea of the advanced modern life, being a kind of "island of peace" in the intense urban life. Its efficiency in the area of fulfilling biophysical (vital, life support) and social (socio cultural) needs permits to create the space of the "modern dream" at the level of architectural volume. This expresses itself through high technologic quality of surfaces and joints, using modern high-end materials, creation of high-quality life support of a house(air, water, heating, protection from external factors); at the level of interior solutions and objects participating in these solutions, through innovative technologies for creation of increased comfort of life, time saving and simplification of life support with simultaneous increase of its quality (storage systems, minimization of objects in interior, easy to clean surfaces).

\subsection{Representation of Elite Benefits in the Minimal Living Architectural Space}

Architectural living space is a social space, because its main purpose is an optimal support of one of the parts of the person's social life.
The analysis of the architectural space concepts is performed in the review by A. G. Rappaport ${ }^{18}$ : Space in an architectural thinking is not like the absolute space of Newtonian physics or space-time of the general relativity theory. It is rather a cultural, experienced by the person space, which is not only reflected in thinking, but is generated by it. On the basis of the analysis of numerous concepts of space in architecture, the science, the art in the $20^{\text {th }}$ century, A. Rappaport revealed a number of the most important functions, through which the space and spatial ideas implement themselves in thinking and culture. Among them he distinguishes the most essential one - reontological function, which, being the function of spatial ideas, aids in establishment of a new picture of the world while abandoning the old paradigm. Agreeing with him about the significance of this function, let us point out two more, in our opinion the most essential ones: the epistemological and the cognitive communication functions. The epistemological function lets the space become the descriptive form of the world, and the cognitive communication function - by means of the space and spatial ideas, enables to see common patterns of existence of multi-object phenomena. Put it differently, space, as a material implementation of the totality of physical and social preferences of an individual, has the top importance in conveying stratification signs, including social differentiation, and gives the society a possibility to decipher the code contained in this space. So we can speak of architectural living space as an object, which contains codes and signs of social stratification.

Previously we revealed a number of features of modern architecture, which got further development in architectural minimalism: geometrical simple form; relation of architecture with nature; simplification of functional links ${ }^{19}$. Minimalist architecture can be referred to the developing tendency inside the main modernist movement continuing its main genetic line, and at the same time we can notice features in it, which make this architecture kin to postmodernism and the consumer society ${ }^{20-23}$. Therefore, it is logical to assume, that the language of modernist architecture is still used in minimal architecture, but now as a tool for representation of values of the consumer society.

Ye. G. Lapshyna ${ }^{24}$ also performed analysis of spatial architectural concepts of the $20^{\text {th }}$ century from the standpoint of static and dynamic aspect of architectural space. The author places a special emphasis on works by Le Corbusier, F. L. Wright and S. Giedion as the most 
influential theorists of the first half of the $20^{\text {th }}$ century that laid foundations of the modernist architectural and spatial theory.

Thus Le Corbusier laid down five new principles of house building (flat roof, support poles, free planning, band windows, façade that is free from details). So he freed the house from the traditional way of living. He aspired to plain architecture growing from reasonable construction and modern materials (metal, reinforced concrete, glass). Free planning offered by Le Corbusier destroyed ideas of the traditional way of life, formed a new notion of freedom ("value of freedom"). Such planning solution, rather the way of living it forms, creates conditions in human mind when an individual can take independent decisions at the level of way of life and his style, but generally in the personal life turns way of life into a dynamic process. Free planning, that was preserved in the minimalistic architectural space in terms of the idea, is therefore a representation of the "value of freedom".

F. L. Wright developed the idea of a modern house built on the principles of "new organic architecture" in his creativity, taking a Japanese traditional house for a prototype endeavoring to breathe the very life in the "car for life". Architectural objects of F. L. Wright have a plain geometrical shape using natural materials (wood, stone) and landscape of the territory. His objects feature both the idea of open plan (unified flowing space in the secular part of the house), and open form inside out into the environment due to vast glazing, which in effect combines it with the ideas of Le Corbusier and, Mies van der Rohe. Nonetheless, the authors fulfill these ideas in different ways and it leads to different esthetic results. Wright does not use a frame structure with a column grid, like the above-mentioned authors do. He uses brick walls, pylons of unworked stone, glass panels, which unify the objects with the environment. Let us point out an important aspect proposed by Wright-opening the limits of the architectural house into the environment. The modernist idea of the form of architectural space opened inside out in the modern man-made space of the city and minimalist dwelling became a representation of the "value of nature".

The "Less is more" slogan by Mies van der Rohe became an ideological reflection of the modernist architecture (the international style), underlain by industrial utility and saving on extravagance connected with maximal derivation of profit with the least expenditures. Simplified life created in such spacelets tie the notion of "time" with the notion of "space", make them a new value. Saving time, which directly follows from simplified life, created a new value of such space. Having noticed that, S. Giedion ${ }^{25}$ introduced the fourth coordinate in the notion of "space" - time - during the study of theoretical modernist concepts. He distinguished two approaches to solution of the space - rational and emotional. Let us dwell on the rational solution of minimal architectural space, because it allows streamlining and ordering the quick pace of the city life, i.e. time. This is the aspect that is important for grounding our hypothesis. Rational solution of the living space (nothing unnecessary) and its elements (things are reduced to the optimal minimum, ordered and functional, sorted in closed niches and cells) became a representation of the "value of time".

The "Less is more" slogan by Mies van der Rohein regard to saving on extravagance led to creation of modern architecture with homogenous surfaces and absence of details. This was utilized by minimalist architects to form semantically and information uncharged architectural space letting keep the person away from adverse effects and excess of information of the consumerist society. Simplicity and emptiness inside and outside such architecture became a representation of the "value of peace".

The representation of elite social benefits in the minimalist space of dwelling totally forms its prime value - the "value of space". This value is used in the consumerist world for bringing anti-consumerism back to the consumer society using its desire of belonging to higher social groups by creating new forms of pleasure-"refusal from things" and "possession of space". Getting involved in this consumerist game, a person becomes a participant of the consumer society again. An individual, through the willing to own "the best", is introduced into the world of consumerism unnoticeably for him in full confidence that he, via minimalist architectural living space, acquires freedom, starts to control his own time, gets nature that he is short of and finds peace that he needs so much.

\section{Conclusion}

The physical value of the modern minimal architectural space is directly connected with its location and size, and also the quality of life provided in this space. Reduction of "aggressiveness" of the urban environment is achievable 
Table 1. The Reflection of Interconnection between Modernist Ideas, Elite Social Benefits and their Representation in the Minimalist Architectural Living Space

\begin{tabular}{|c|c|c|}
\hline Modernist ideas & $\begin{array}{l}\text { Representation of elite social benefits in } \\
\text { architectural living space }\end{array}$ & Elite social benefits of the modern society \\
\hline "Free plan" byLe Corbusier & $\begin{array}{l}\text { Free interior planning; vast empty space not filled } \\
\text { with things; a lot of light; remoteness from other } \\
\text { buildings. }\end{array}$ & $\begin{array}{l}\text { "Value of freedom" } \\
\text { Life in own rhythm, creation of own in- } \\
\text { dividual way of living with a possibility of } \\
\text { its transformation; freedom from people, } \\
\text { information and things. }\end{array}$ \\
\hline $\begin{array}{l}\text { "Organic architecture"by F. } \\
\text { L. Wright: mutual pene- } \\
\text { tration of architecture and } \\
\text { environment }\end{array}$ & $\begin{array}{l}\text { Advantageous location (isolation from other } \\
\text { buildings), existence of natural or urban land- } \\
\text { scape around (open city perspectives, "city in plain } \\
\text { sight"), inherent value of space (cult of emptiness, "a } \\
\text { lot of air"). }\end{array}$ & $\begin{array}{l}\text { "Value of nature" } \\
\text { Return of nature to the living environment } \\
\text { of man. }\end{array}$ \\
\hline $\begin{array}{l}\text { "Less is more" by Mies van } \\
\text { der Rohe }\end{array}$ & $\begin{array}{l}\text { Rational solution of internal living space and } \\
\text { elements of this space ("the required minimum", } \\
\text { "everything is in its place"), absence of things } \\
\text { outside and empty surfaces in interior space (easier } \\
\text { cleaning), maximal technical equipment of house } \\
\text { ("invisible assistants", "smart house", presence of } \\
\text { intricate mechanisms simplifying everyday life and } \\
\text { hidden inside surfaces). }\end{array}$ & $\begin{array}{l}\text { "Value of time" } \\
\text { Rationalization of everyday life to reduce } \\
\text { temporary interval of fulfilling household } \\
\text { obligations and domestic cares, freeing time } \\
\text { for rest. }\end{array}$ \\
\hline $\begin{array}{l}\text { "Limitedness"by F. L. } \\
\text { Wright: and "Less is more" } \\
\text { by Mies van der Rohe }\end{array}$ & $\begin{array}{l}\text { Information-free environment ("simplicity"), } \\
\text { physically empty and semantically uncharged space } \\
\text { ("emptiness"); employment of the cutting-edge } \\
\text { technologies and materialsabsorbing noise ("si- } \\
\text { lence"). }\end{array}$ & $\begin{array}{l}\text { "Value of peace" } \\
\text { Possibility of solitude and rest in silence } \\
\text { that provides recovery of sensorial balance- } \\
\text { in aggressive urban environment. }\end{array}$ \\
\hline
\end{tabular}

by its improved location-partial removal of the controversy between the city and nature (availability of natural landscape - beautiful sights, open perspectives). This leads to reduction of psychological discomfort of living in the urban environment creating an illusion of connection with nature (price for house rises because of the "value of nature" included in its price). Free planning offered in minimal architecture creates an illusion of controlling one's own life through the option of free zoning of the residential space and the freedom from things (the price for house rises because of the "value of freedom"). The reduction of the city noise by using cutting-edge house building technologies creates a sense of peace (rise of price for house due to the "value of peace" in its price). Naturally, the price for such residence is high due to the high quality of life it provides in the urban environment. The maximal technical equipment of house, proximity of transport junctions, accessibility of developed infrastructure, which save time in the city, play not a small role here, and the high technological comfort minimizes household problems (the increase of cost of housing due to the availability of the materialized "value of time"). All of the above-mentioned points form its maximum cost, which includes the "value of space" as such, elevating the minimalist living architectural space to the level of expensive elite goods. The "value of space" includes both its big size, and emptiness (the absence of constraint inside and outside the architectural space), which allow enjoying space without people. Its material value is currently beyond doubt letting person who owns it fit in the rhythm of urban life with the least physiological losses, and at the same time mark himself as an owner of social benefits (the high quality of life) not affordable for everyone.

\section{References}

1. Levy SJ. Symbols for Sale. Harvard Business Review. 1959 Aug; 37:117-9.

2. Kuznetsov DA, Maksimov MA. Kollektivniysubektantikonsumerizma: $\mathrm{k}$ postanovkeproblemy [Collective Subject of Anticonsumerism: Revisiting the Setting of the Problem]. Philosophy and Society. 2013; Available from: http://cyberleninka.ru/article/n/kollektivnyy-subekt-antikonsyumerizma-k-postanovke-problemy 
3. Veblen T. The Theory of the Leisure Class. Moscow; 1984.

4. Baudrillard J. The Consumer Society. Myths and Structures. London: SAGE; First published in 1970; 1997.

5. Gudkova T. Minimalist Architectural Space as a Carrier of Connotations of Social Benefits (High Quality of Life). Review of European Studies. 2014 Dec; 6(4):122. Available from: http://www.ccsenet.org/journal/index.php/res/article/view/41414/23096

6. Simmel G. Sociology of space. Favorites. In 2 vols. Contemplation of life. Moscow: Jurist. 1996. p. 2.

7. Bourdieu P. Chosesdites. Paris: Minuit; 1987.

8. Barkovskaya AY. Sotsiologicheskayainterpretatsiyakategoriyi 'Sotsialnoeprostranstvo' [Sociological interpretation of the 'Social space' category]. Journal of Volgograd State University, Series7. Philosophy. Sociology and Social Technologies. 2013; Available from: http://cyberleninka.ru/article/n/sotsiologicheskaya-interpretatsiya-kategorii-sotsialnoe-prostranstvo

9. Yarskaia V, Yakovlev L, Petchenkin B, Yezhov O. Prostranstvoivremyasotsialnykhizmeneniy [The space and time of social change]. 2004; Available from: http://ecsocman.hse. $\mathrm{ru} / \mathrm{text} / 19196158 /$

10. Melnikova NN. Stilzhizniiadaptivnayafunktsiya [The way of life and its adaptive function]. Bulletin of South-Ural State University. 2009; 5 (138). Available from: http://cyberleninka.ru/article/n/obraz-zhizni-i-ego-adaptivnayafunktsiya

11. Kiselev EA. Osnovniepodkhody k issledovaniyustilyazhizni vsotsiologii [Main Approaches to Research of Life Style in Sociology].VestnikPenzGU. 2013; 1. Available from: http:// cyberleninka.ru/article/n/osnovnye-podhody-k-issledovaniyu-stilya-zhizni-v-sotsiologii

12. Maslentseva NY. Sotsiologicheskieosnovaniyakontseptsiistilyazhizni [Sociological Grounds of the Life Style Concept].Bulletin of ChelGU. 2010; 31. Available from: http:// cyberleninka.ru/article/n/sotsiologicheskie-osnovaniya-kontseptsii-stilya-zhizni

13. Biryukova EE. The aesthetics of form and content of the architectural space. Abstract of the PhD thesis. Vladimir: State Ped. University. 2003; Available from: http://www. dissercat.com/content/estetika-formy-i-soderzhanie-arkhitekturnogo-prostranstva\#ixzz31Kq1TqLi

14. Pereverzev LB. Proektnayamifoplasticapredmetnogomirazhilishchakakkompleksnogoobekta [Design plastics of subjective world of house as a complex object]. Proceed- ings of VNIITE; TehnicheskayaEstetica. 1981; 31. Available from: http://docme.ru/doc/77682/mifoplastica

15. Kirsanova LI. Filosofsko-antropologicheskiypodkhod $\mathrm{k}$ arhitekture [Philosophical and Anthropological Approach to Architecture]. Territory of new possibilities. Journal of Vladivostok State University for Economics and Service. 2012; Available from: http://cyberleninka.ru/article/n/filosofsko-antropologicheskiy-podhod-k-arhitekture

16. Yakunicheva KN. Yaponskiyteatrkak instrument prognozirovaniyazhiloysredybudushchego [Japanese theatre as forecasting tool for future living space]. International Research Journal. 2013; 6-3 (13):81-7. Available from: http:// cyberleninka.ru/article/n/yaponskiy-teatr-kak-instrument-prognozirovaniya-zhiloy-sredy-buduschego

17. Stevanovic V. A reading of interpretative models of minimalism in architecture. METU JFA. 2013; 30(2): 181-94. Available from: http://jfa.arch.metu.edu.tr/archive/0258-5316/2013/cilt30/sayi_2/181-194.pdf

18. Rappaport AG. Kontseptsiiarkhitekturnogoprostranstva [Concepts of Architectural Space]. 1988; Available from: http://papardes.blogspot.ru/2009/11/blog-post_28.html

19. Gudkova TV, Karyaka KS. Features of modernism, the Japanese traditionalism and modern Japanese architecture (50-70-ies.) and their manifestation in architecture of minimalism. PolzunovskyVestnik. 2013; 4(1). Available from: http://elib.altstu.ru/elib/books/Files/pv2013_04_1/ pdf/062gudkova.pdf

20. Ibelings H. Super modernism: Architecture in the Age of Globalization. Rotterdam: NAI Publishers; 1998.

21. Macarthur J. The look of the object: minimalism in art and architecture, then and now. Architectural Theory Review. 2002; 7(1): 137-48. Available from: http://dx.doi. org/10.1080/13264820209478450

22. Grimshaw M. Soft Modernism: The World of Post-Theoretical Designer. 2004; Available from: http://www.ctheory. net/articles.aspx?id=418\#_ednref24

23. Jencks $\mathrm{CH}$. Critical Modernism: Where is post-modernism going?. Great Britain: Wiley-Academy; 2007.

24. Lapshina EG. Formula novoiyarchitektury - dinamikaprostranstva [The Formula of the New Architecture - the dynamics of the space]. Bulletin of MGSU. 2012; 1. Available from: http://www.vestnikmgsu.ru/index.php/ru/archive/ article/display/57/3

25. Giedion S. Prostranstvo, vremya, arkhitektura [Space, Time, Architecture]. Moscow: Stroizdat; 1984. 